\title{
Optimalisasi Produksi Kopi Bubuk Asli Lampung Dengan Metode Simpleks
}

\author{
The Optimization of Lampung Original Powder Coffee Production \\ With The Simplex Method
}

\author{
Ruchimat Haslan ${ }^{1}$, Nanang Supriadi ${ }^{2}$, Sri Purwanti Nasution ${ }^{3}$ \\ ${ }^{1}$ Jurusan Pendidikan Matematika, Fakultas Tarbiyah dan Keguran, UIN Raden Intan Lampung \\ ${ }^{2,3}$ Fakultas Tarbiyah dan Keguruan, UIN Raden Intan Lampung \\ ruchimathaslan59@gmail.com, nanangsupriadi@gmail.com, sripurwanti@yahoo.co.id
}

\begin{abstract}
Abstrak. Tujuan penelitian ini adalah untuk mengoptimalkan produksi kopi bubuk dengan metode simpleks dan berbantu software Lindo dalam produksi kopi bubuk di Industri Rumahan Kopi Bubuk Asli Lampung. Metode simpleks adalah suatu metode yang digunakan untuk memecahkan masalah linear programming yang meliputi banyak pertidaksamaan dan banyak variabel dengan perhitungan berulang-ulang (iterasi) sampai mencapai solusi optimal. Penelitian ini adalah studi pustaka yang merupakan telaah dari literatur dengan mengkaji buku-buku, literatur-literatur, catatan-catatan, dan laporan-laporan yang berhubungan dengan masalah yang dipecahkan. Hasil dari penelitian ini menunjukkan bahwa setelah dilakukan perhitungan dengan metode simpleks dan berbantu software Lindo, jumlah produksi optimal yaitu 46 kemasan 1 dan 163 kemasan 2, sehingga diperoleh keuntungan produksi optimal sebesar Rp. 2.541.500 dengan ketersediaan bahan baku yang ada.
\end{abstract}

Kata Kunci: Linear Programming, Metode Simpleks, Optimalisasi, Lindo 6.1

\begin{abstract}
The purpose of this research is to optimize the production of coffee powder with simplex method and Lindo software assisted in the production of coffee powder in Lampung Pure Coffee Industry Original Lampung. The simplex method is a method used to solve linear programming problems that include many inequalities and many variables with repeated calculations (iterations) until it reaches the optimal solution. This study is a literature study which is a study of the literature by reviewing books, literature, records, and reports relating to the problem solved. The result of this research shows that after calculation with simplex method and assisted software Lindo, optimum production amount that is 46 pack 1 and 163 pack 2, so that obtained optimal production profit equal to IDR 2.541 .500 with the availability of existing raw materials.
\end{abstract}

Keywords: Linear Programming, Simplex Method, Optimization, Lindo 6.1

\section{Pendahuluan}

Pada saat ini, banyak perusahaan yang bergerak dibidang industri, baik industri besar, industri menengah maupun industri kecil. Persaingan bisnis akhir-akhir ini semakin ketat dan sulit. Hal ini dapat dilihat dari semakin bertambahnya perusahaan. Kondisi ini menyebabkan banyak perusahaan saling berlomba-lomba untuk menjadi yang terbaik dan memiliki hasil yang berkualitas dibidangnya [9]. Tingkat persaingan yang semakin kompetitif sering dihadapkan pada perusahaan yang bergerak dibidang industri [6]. Untuk dapat bersaing dalam dunia bisnis perusahaan harus memilih lokasi yang strategis dan tersedianya produk barang untuk memenuhi tuntutan pasar. Semakin luas pengetahuan yang dimiliki seseorang/perusahaan maka akan semakin tinggi pula taraf berpikirnya [2]. Kegiatan produksi perusahaan memiliki peranan sangat penting. Karena proses produksi mendukung jalannya perusahaan dan menentukan besarnya pendapatan perusahaan $[5,12]$. 
Lampung adalah sebuah Provinsi paling selatan di Pulau Sumatera, Indonesia, dengan Ibukota terletak di Bandar Lampung [7]. Sebelah utara berbatasan dengan Bengkulu dan Sumatera Selatan. Provinsi Lampung memiliki banyak pulau-pulau, tempat-tempat wisata, dan memiliki wilayah yang banyak mengembangkan hasil bumi dalam sub-sektor perkebunan kopi. Kopi merupakan salah satu komoditas unggulan dalam sub-sektor perkebunan karena memiliki peluang pasar yang baik di dalam negeri maupun luar negeri [11]. Sebagian besar produksi kopi di Indonesia merupakan komoditas perkebunan yang dijual ke pasar dunia. Hal ini juga dibuktikan dengan banyak jumlah pengusaha kopi yang tersebar di Provinsi Lampung, baik untuk skala kecil atau menengah [3]. Untuk dapat bersaing di pasar dunia maka perusahaan memerlukan salah satu tujuan adanya manajemen produksi. Dengan adanya produksi dan manajemen yang bagus perusahaan harus mencari ide-ide terbaru dalam produksi sehingga dapat meningkatkan hasil produksi dalam perusahaan [5].

Permasalahan yang berkaitan dengan proses memaksimalkan keuntungan atau meminimalkan biaya disebut optimalisasi [1]. Mengingat bahwa faktor-faktor produksi, tingkat keuntungan, dan produk yang dihasilkan memiliki hubungan linear, maka diperlukan pemecahan masalah optimalisasi [4,14]. Dalam hal ini, diperlukan suatu alat analisis linear yaitu menggunakan metode Simpleks. Simpleks adalah suatu metode yang digunakan untuk memecahkan masalah linear programming yang meliputi banyak pertidaksamaan dan banyak variabel dengan perhitungan berulang-ulang (iterasi) hingga mencapai solusi optimal [9].

Memecahkan masalah linear programming perlu dilakukan penentuan mengenai kendala-kendala yang ada, dan diubah ke dalam bentuk model Matematika. Membuat model Matematika dalam suatu masalah linear programming adalah menentukan fungsi tujuan beserta kendala yang harus dipenuhi [8]. Industri Rumahan Kopi Bubuk Asli Lampung dalam memproduksi dua jenis kemasan kopi bubuk memiliki beberapa kendala yaitu kopi bubuk yang dikemas dengan bungkus yang bagus dan menarik serta kopi bubuk yang dikemas dengan bungkus yang biasa. Kedua jenis kemasan kopi bubuk tersebut memiliki kualitas dan rasa yang sama, namun dibedakan oleh kemasan dan harga. Kendala ini yang menjadi salah satu penyebab belum tercapainya keuntungan optimum. Karena kurangnya pemahaman ilmu Matematika pada Industri Rumahan Kopi Bubuk Asli Lampung dalam proses produksi sehingga belum menerapkan metode Simpleks. Oleh karena itu, penelitian yang akan dilakukan dan dibahas pada artikel ini adalah Optimalisasi Produksi Kopi Bubuk Asli Lampung dengan Metode Simpleks.

Optimalisasi adalah suatu keseimbangan yang dicapai karena memilih alternatif terbaik dari beberapa kriteria tertentu yang ada [1,13]. Persoalan optimalisasi pada dasarnya adalah bagaimana membuat nilai suatu fungsi dari beberapa variabel menjadi maksimum/minimum dengan memperhatikan kendala-kendala yang ada diantaranya adalah kendala berupa tenaga kerja, modal, dan material.

\section{Metode Simpleks}

Metode Simpleks merupakan prosedur atau algoritma yang digunakan untuk menghitung dan menyimpan banyak angka pada iterasi-iterasi awal dan untuk pengambilan keputusan pada iterasiiterasi berikutnya. Metode Simpleks digunakan untuk menyelesaikan masalah-masalah program linear yang meliputi banyak pertidaksamaan dan banyak variabel. Bentuk umum persamaan fungsi tujuan untuk maksimalkan adalah:

$$
\mathrm{Z}=\mathrm{c}_{1} \mathrm{x}_{1}+\mathrm{c}_{2} \mathrm{x}_{2}+\ldots
$$

dimana: $\mathrm{Z}=$ keuntungan maksimum

$\mathrm{c}_{\mathrm{j}}=$ kontribusi keuntungan produk ke- $\mathrm{j}$

$\mathrm{x}_{\mathrm{j}}=$ kelompok produk ke-j [9]. 
Langkah-langkah penyelesaian dengan metode simpleks adalah:

1. Menentukan fungsi tujuan dan fungsi-fungsi kendala

2. Mengubah fungsi tujuan dan fungsi kendala ke dalam bentuk standar

3. Membuat tabel simpleks awal

4. Melakukan iterasi

5. Melakukan iterasi kembali sampai tidak ada nilai negatif pada baris Z

Adapun bentuk tabel simpleks ditunjukkan pada Tabel 1 sebagai berikut:

Tabel 1. Bentuk Tabel Simpleks

\begin{tabular}{|c|c|c|c|c|c|c|c|c|}
\hline \multirow{2}{*}{$\begin{array}{c}\text { Variabel } \\
\text { Dasar (VD) }\end{array}$} & \multirow{2}{*}{$\mathrm{Z}$} & \multirow{2}{*}{$X_{1} \quad X_{2}$} & \multirow{2}{*}{$\ldots$} & \multicolumn{4}{|c|}{ Slack Variabel } & \multirow{2}{*}{$\begin{array}{c}\text { Nilai } \\
\text { Kanan } \\
(\mathrm{NK})\end{array}$} \\
\hline & & & & $X_{n}$ & $X_{n+1}$ & $X_{n+2}$ & $\ldots \quad X_{n+m}$ & \\
\hline $\mathrm{Z}$ & 1 & $-\mathrm{C}_{11}-\mathrm{C}_{22}$ & $\ldots$ & $-C_{n} 0$ & 0 & 0 & & 0 \\
\hline$X_{n+1}$ & 0 & & & & & & & \\
\hline$X_{n+2}$ & 0 & $a_{11} \quad a_{22}$ & & $a_{n}$ & 1 & & 0 & $\mathrm{~b}_{1}$ \\
\hline- & - & - & & - & - & - & - & - \\
\hline- & - & - & & - & - & - & - & - \\
\hline - & - & - & & - & - & - & - & - \\
\hline$X_{n+m}$ & 0 & $a_{m 1} \quad a_{m 2}$ & & & $\mathrm{mn}$ & 0 & 1 & $\mathrm{~b}_{\mathrm{m}}$ \\
\hline
\end{tabular}

dimana:

$\mathrm{m}=$ banyaknya fungsi batasan (kendala)

$\mathrm{n}$ = banyaknya variabel output

$\mathrm{b}_{1}=$ batasan sumber 1

$\mathrm{b}_{2}=$ batasan sumber 2

$\mathrm{b}_{\mathrm{m}}=$ batasan sumber $\mathrm{m}[10]$.

Metode penelitian yang digunakan dalam artikel ini dirangkaikan dalam bentuk diagram alir (flowchart) yang ditunjukkan pada Gambar 1.

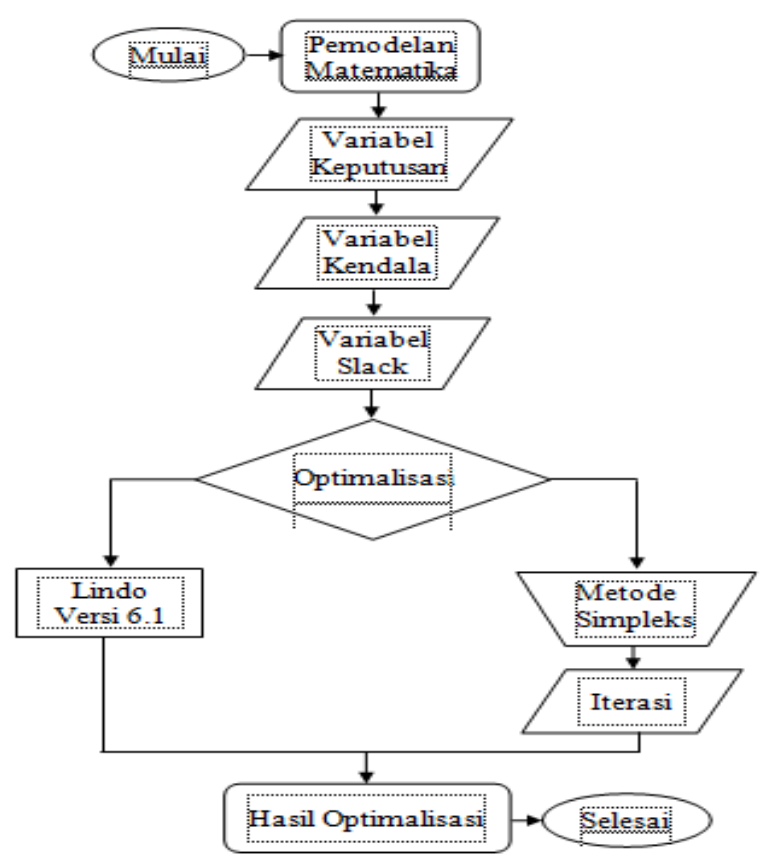

Gambar 1. Bentuk Diagram Alir (Flowchart) 


\section{Hasil dan Pembahasan}

Penelitian ini dilaksanakan di Industri Rumahan Kopi Bubuk Asli Lampung yang beralamat di Jalan Pulau Tegal Gang Barokah III No. 95 Rt. 01 LK. III Way Dadi, Sukarame, Bandar Lampung. Usaha ini memproduksi dua jenis produk yaitu produk 1 dan produk 2. Produk 1 adalah produk yang dikemas dengan bungkus yang bagus dan menarik. Produk 2 adalah produk yang dikemas dengan bungkus yang biasa. Proses produksi kopi bubuk ini sudah menggunakan teknologi mesin untuk mempermudah proses produksi. Adapun langkah-langkah dalam proses produksi adalah sebagai berikut:

1. Penyiapan bahan baku

2. Penggorengan

3. Penyortiran

4. Pengilingan

5. Penimbangan

6. Pengemasan

Berdasarkan hasil wawancara yang peneliti lakukan secara langsung kepada narasumber yang merupakan pemilik dari usaha kopi bubuk tersebut maka akan disajikan pada Tabel 2 data produksi periode satu bulan sebagai berikut:

Tabel 2. Ketersediaan Produksi dalam Satu Periode (April 2018)

\begin{tabular}{|c|l|c|c|}
\hline No. & \multicolumn{1}{|c|}{ Faktor Produksi } & Ketersediaan & Satuan \\
\hline 1. & $\begin{array}{l}\text { Bahan Baku } \\
\text { a. Biji Kopi }\end{array}$ & 150 & Kg \\
\hline 2. & $\begin{array}{l}\text { Plastik } \\
\text { a. Kemasan 1 } \\
\text { b. Kemasan 2 }\end{array}$ & $\begin{array}{c}1.500 \\
\text { Rupiah } \\
\text { Rupiah }\end{array}$ \\
\hline 3. & Tenaga Kerja & 500 & Orang \\
\hline 4. & Jam Tenaga Kerja & 54 & Jam \\
\hline 5. & $\begin{array}{l}\text { Jam Kerja Mesin } \\
\text { a. Penggorengan } \\
\text { b. Penggilingan }\end{array}$ & 15 & Jam \\
\hline 6. & Biaya Operasional & 10 & Jam \\
\hline 7. & $\begin{array}{l}\text { Batasan Produksi } \\
\text { a. Kopi bubuk yang dikemas } \\
\text { dengan bungkus yang bagus dan } \\
\text { menarik (x } x_{1}\end{array}$ & 5.500 .000 & Kemasan \\
& $\begin{array}{l}\text { Kopi bubuk yang dikemas } \\
\text { dengan bungkus yang biasa (x } 2)\end{array}$ & 160 & Kemasan \\
\hline
\end{tabular}

Sumber: Industri Rumahan Kopi Bubuk Asli Lampung, 2018

Berdasarkan Tabel 2 Industri Rumahan Kopi Bubuk Asli Lampung dalam proses produksi akan selalu dibatasi oleh berbagai kendala. Kendala-kendala tersebut adalah bahan baku, plastik, tenaga kerja, jam tenaga kerja, jam kerja mesin, dan biaya operasional. Pengolahan data dengan menggunakan metode Simpleks dan berbantu software lindo dapat memperlihatkan hasil optimal dari proses produksi di Industri Rumahan Kopi Bubuk Asli Lampung. Industri Rumahan ini akan memproduksi dua jenis produk dengan bahan baku dan kualitas yang sama namun beda kemasan. 
Dalam memproduksi biji kopi ada dua jenis mesin yang bekerja yaitu mesin penggorengan dan mesin penggilingan. Di bawah ini adalah jam kerja mesin pada tiap kemasan, sebagaimana ditunjukkan dalam Tabel 3.

Tabel 3. Jam Kerja Mesin Produksi

\begin{tabular}{|l|c|c|c|}
\hline \multirow{2}{*}{ Mesin } & $\begin{array}{c}\text { Kapasitas/bulan } \\
\text { (detik) }\end{array}$ & \multicolumn{2}{|c|}{ Jam kerja tiap produk } \\
\cline { 3 - 4 } & & $\mathrm{X}_{1}$ & $\mathrm{X}_{2}$ \\
\hline Penggorengan & 54000 & 240 & 240 \\
\hline Penggilingan & 36000 & 120 & 120 \\
\hline Total & 90000 & 360 & 360 \\
\hline
\end{tabular}

Sumber: Industri Rumahan Kopi Bubuk Asli Lampung, 2018.

Adapun biaya produksi untuk menghasilkan dua jenis produk dalam industri rumahan ini berupa biaya bahan baku, biaya tenaga kerja, dan biaya tambahan lainnya yang disebut sebagai biaya operasional. Biaya yang digunakan dalam memproduksi dua jenis kopi bubuk per 500gr, sebagaimana ditunjukkan pada Tabel 4.

Tabel 4. Biaya Produksi dan Harga Jual Produk

\begin{tabular}{|c|c|c|c|c|c|c|}
\hline No & Produk & $\begin{array}{c}\text { Biaya } \\
\text { tenaga } \\
\text { kerja/ } \\
\text { kemasan }\end{array}$ & $\begin{array}{c}\text { Biaya } \\
\text { lainnya/ } \\
\text { kemasan }\end{array}$ & $\begin{array}{c}\text { Biaya } \\
\text { bahan } \\
\text { baku/ } \\
\text { kemasan }\end{array}$ & $\begin{array}{c}\text { Total } \\
\text { biaya/ } \\
\text { kemasan }\end{array}$ & $\begin{array}{c}\text { Harga } \\
\text { jual/ } \\
\text { kemasan }\end{array}$ \\
\hline 1. & $\mathrm{X}_{1}$ & 2000 & 1500 & 18000 & 21500 & 35000 \\
\hline 2. & $\mathrm{X}_{2}$ & 1000 & 500 & 18000 & 19500 & 30000 \\
\hline
\end{tabular}

Sumber: Industri Rumahan Kopi Bubuk Asli Lampung, 2018.

Industri Rumahan Kopi Bubuk Asli Lampung memproduksi dua jenis produk kopi bubuk yaitu kopi bubuk yang dikemas dengan bungkus yang bagus dan menarik serta kopi bubuk yang dikemas dengan bungkus yang biasa. Satu bungkus kopi bubuk yang dikemas dengan bungkus yang bagus dan menarik memerlukan bahan baku berupa biji kopi sebanyak 720 gr. Satu bungkus kopi bubuk yang dikemas dengan bungkus yang biasa memerlukan bahan baku berupa biji kopi sebanyak 720 gr. Industri Rumahan Kopi Bubuk Asli Lampung hanya mempunyai persediaan bahan baku berupa biji kopi kurang dari $150 \mathrm{~kg}$. Untuk mengemas kopi bubuk tersebut terdapat 2 jenis plastik yaitu plastik yang bagus dengan harga Rp.1.500 dan plastik yang biasa dengan harga Rp.500. Sedangkan harga 2 jenis plastik tersebut kurang lebih sebesar Rp.150.000. Industri rumahan ini mempekerjakan 2 orang tenaga kerja. Masing-masing tenaga kerja mendapatkan upah per kemasan sebesar Rp.2000 dan Rp.1000 sehingga upah per tenaga kerja tersebut kurang lebih Rp.500.000. Waktu yang dibutuhkan 2 tenaga kerja dalam produksi kopi bubuk per kemasan yaitu 5 menit dan bekerja selama kurang lebih $54 \mathrm{jam} / \mathrm{bulan}$. Keuntungan tiap produk yang diperoleh untuk kopi bubuk yang dikemas dengan bungkus yang bagus dan menarik sebesar Rp.14.500, sedangkan kopi bubuk yang dikemas dengan bungkus yang biasa sebesar Rp.11.500. Jika industri rumahan kopi bubuk asli lampung memiliki modal sebesar Rp. 5.500 .000 dengan biaya operasional tiap-tiap produk adalah Rp.21.500 dan Rp.19.500. Maka akan dapat ditentukan berapa jumlah masing-masing produk kopi bubuk yang akan diproduksi agar memperoleh keuntungan maksimum jika batasan produksi masing-masing produk minimum40 kemasan kopi bubuk yang dikemas dengan bungkus yang bagus dan menarik, dan 160 kemasan kopi bubuk yang dikemas dengan bungkus yang biasa.

Untuk memecahkan masalah diatas menggunakan langkah-langkah sebagai berikut: 
1. Menentukan variabel keputusan dari permasalahan tersebut.

$x_{I}=$ kopi bubuk yang dikemas dengan bungkus yang bagus dan menarik (500gr)

$x_{2}=$ kopi bubuk yang dikemas dengan bungkus yang biasa (500gr)

2. Menentukan kendala-kendala dari permasalahan tersebut.

Biji kopi $\quad=720 x_{1}+720 x_{2} \leq 150.000$

Plastik $\quad=1500 x_{1}+500 x_{2} \leq 150.000$

Tenaga Kerja $\quad=2000 x_{1}+1000 x_{2} \leq 500.000$

Jam Kerja Mesin $=360 x_{1}+360 x_{2} \leq 90.000$

Jam Kerja Tenaga Kerja $\quad=300 x_{1}+300 x_{2} \leq 194.400$

Biaya operasional $=21.500 x_{1}+19.500 x_{2} \leq 5.500 .000$

$x_{1} \geq 40$

$x_{2} \geq 160$

3. Menentukan fungsi tujuan dari permasalahan tersebut.

$\operatorname{Max} \mathrm{Z}=14.500 x_{1}+11.500 x_{2}$

4. Mengubah pertidaksamaan $(\leq)$ menjadi $(=)$ dengan menambahkan variabel slack dan variabel buatan untuk pertidaksamaan $(\geq)$ ke sisi kiri kendala.

$720 x_{1}+720 x_{2}+s_{1}=150.000$

$1500 x_{1}+500 x_{2}+s_{2}=150.000$

$2000 x_{1}+1000 x_{2}+\mathrm{s}_{3}=500.000$

$360 x_{1}+360 x_{2}+s_{4}=90.000$

$300 x_{1}+300 x_{2}+s_{5}=194.400$

$21.500 x_{1}+19.500 x_{2}+s_{6}=5.500 .000$

$x_{1}-s_{7}+a_{1}=40$

$x_{2}-s_{8}+a_{2}=160$

$\mathrm{Z}=14.500 x_{1}+11.500 x_{2}+0 s_{1}+0 s_{2}+0 s_{3}+0 s_{4}+0 s_{5}+0 s_{6}+0 s_{7}+0 s_{8}-m a_{1}-m a_{2}$

$\mathrm{Z}-14.500 x_{1}-11.500 x_{2}-0 s_{1}-0 s_{2}-0 s_{3}-0 s_{4}-0 s_{5}-0 s_{6}-0 s_{7}-0 s_{8}+m a_{1}+m a_{2}=0$

5. Membuat tabel simpleks dengan memasukkan semua koefisien-koefisien variabel keputusan dan variabel slack tersebut.

Tabel 5. Tabel Simpleks Awal

\begin{tabular}{|c|c|c|c|c|c|c|c|c|c|c|c|c|c|c|}
\hline VD & X1 & X2 & S1 & S2 & S3 & S4 & S5 & S6 & Artc1 & Sur7 & Artc2 & Sur8 & NK & RASIO \\
\hline Z & -14500 & -11500 & 0 & 0 & 0 & 0 & 0 & 0 & 0 & 0 & 0 & 0 & 0 & \\
\hline S1 & 720 & 720 & 1 & 0 & 0 & 0 & 0 & 0 & 0 & 0 & 0 & 0 & 150000 & \\
\hline S2 & 1500 & 500 & 0 & 1 & 0 & 0 & 0 & 0 & 0 & 0 & 0 & 0 & 150000 & \\
\hline S3 & 2000 & 1000 & 0 & 0 & 1 & 0 & 0 & 0 & 0 & 0 & 0 & 0 & 500000 & \\
\hline S4 & 360 & 360 & 0 & 0 & 0 & 1 & 0 & 0 & 0 & 0 & 0 & 0 & 90000 & \\
\hline S5 & 300 & 300 & 0 & 0 & 0 & 0 & 1 & 0 & 0 & 0 & 0 & 0 & 194400 & \\
\hline S6 & 21500 & 19500 & 0 & 0 & 0 & 0 & 0 & 1 & 0 & 0 & 0 & 0 & 5500000 & \\
\hline Artc1 & 1 & 0 & 0 & 0 & 0 & 0 & 0 & 0 & 1 & -1 & 0 & 0 & 40 & \\
\hline Artc2 & 0 & 1 & 0 & 0 & 0 & 0 & 0 & 0 & 0 & 0 & 1 & -1 & 160 & \\
\hline
\end{tabular}


6. Selanjutnya melakukan iterasi untuk mencari nilai $Z$ maksimumnya. Dari hasil perhitungan menggunakan iterasi akan diperoleh tabel baru.

Tabel 6. Tabel Iterasi Pertama

\begin{tabular}{|c|c|c|c|c|c|c|c|c|c|c|c|c|c|c|}
\hline VD & X1 & X2 & S1 & S2 & S3 & S4 & S5 & S6 & Artc1 & Sur7 & Artc2 & Sur8 & NK & RASIO \\
\hline Z & $-\mathrm{M}-$ & $-\mathrm{M}-$ & 0 & 0 & 0 & 0 & 0 & 0 & 0 & $\mathrm{M}$ & 0 & $\mathrm{M}$ & $-200 \mathrm{M}$ & \\
\hline $\mathrm{S} 1$ & 720 & 720 & 1 & 0 & 0 & 0 & 0 & 0 & 0 & 0 & 0 & 0 & 150000 & 208,3 \\
\hline S2 & 1500 & 500 & 0 & 1 & 0 & 0 & 0 & 0 & 0 & 0 & 0 & 0 & 150000 & 100 \\
\hline S3 & 2000 & 1000 & 0 & 0 & 1 & 0 & 0 & 0 & 0 & 0 & 0 & 0 & 500000 & 250 \\
\hline S4 & 360 & 360 & 0 & 0 & 0 & 1 & 0 & 0 & 0 & 0 & 0 & 0 & 90000 & 250 \\
\hline S5 & 300 & 300 & 0 & 0 & 0 & 0 & 1 & 0 & 0 & 0 & 0 & 0 & 194400 & 648 \\
\hline S6 & 21500 & 19500 & 0 & 0 & 0 & 0 & 0 & 1 & 0 & 0 & 0 & 0 & 5500000 & 255,8 \\
\hline Artc1 & 1 & 0 & 0 & 0 & 0 & 0 & 0 & 0 & 1 & -1 & 0 & 0 & 40 & 40 \\
\hline Artc2 & 0 & 1 & 0 & 0 & 0 & 0 & 0 & 0 & 0 & 0 & 1 & -1 & 160 & $\sim$ \\
\hline
\end{tabular}

Tabel 7. Tabel Iterasi Kedua

\begin{tabular}{|c|c|c|c|c|c|c|c|c|c|c|c|c|c|c|}
\hline VD & $\mathrm{X} 1$ & $\mathrm{X} 2$ & $\mathrm{~S} 1$ & $\mathrm{~S} 2$ & $\mathrm{~S} 3$ & $\mathrm{~S} 4$ & $\mathrm{~S} 5$ & $\mathrm{~S} 6$ & Artc1 & Sur7 & Artc2 & Sur8 & NK & RASIO \\
\hline $\mathrm{Z}$ & 0 & $\begin{array}{c}-\mathrm{M}- \\
11500\end{array}$ & 0 & 0 & 0 & 0 & 0 & 0 & $\mathrm{M}+14500$ & $\begin{array}{c}- \\
14500\end{array}$ & 0 & $\mathrm{M}$ & $\begin{array}{c}-160 \mathrm{M}+ \\
580000\end{array}$ \\
\hline $\mathrm{S} 1$ & 0 & 720 & 1 & 0 & 0 & 0 & 0 & 0 & -720 & 720 & 0 & 0 & 121200 & 168,3 \\
\hline $\mathrm{S} 2$ & 0 & 500 & 0 & 1 & 0 & 0 & 0 & 0 & -1500 & 1500 & 0 & 0 & 90000 & 180 \\
\hline S3 & 0 & 1000 & 0 & 0 & 1 & 0 & 0 & 0 & -2000 & 2000 & 0 & 0 & 420000 & 420 \\
\hline S4 & 0 & 360 & 0 & 0 & 0 & 1 & 0 & 0 & -360 & 360 & 0 & 0 & 75600 & 210 \\
\hline S5 & 0 & 300 & 0 & 0 & 0 & 0 & 1 & 0 & -300 & 300 & 0 & 0 & 182400 & 608 \\
\hline S6 & 0 & 19500 & 0 & 0 & 0 & 0 & 0 & 1 & -21500 & 21500 & 0 & 0 & 4640000 & 237,9 \\
\hline X1 & 1 & 0 & 0 & 0 & 0 & 0 & 0 & 0 & 1 & -1 & 0 & 0 & 40 & $\sim$ \\
\hline Artc2 & 0 & 1 & 0 & 0 & 0 & 0 & 0 & 0 & 0 & 0 & 1 & -1 & 160 & 160 \\
\hline
\end{tabular}

Tabel 8. Tabel Iterasi Ketiga

\begin{tabular}{|c|c|c|c|c|c|c|c|c|c|c|c|c|c|c|}
\hline VD & $\mathrm{X} 1$ & $\mathrm{X} 2$ & $\mathrm{~S} 1$ & $\mathrm{~S} 2$ & $\mathrm{~S} 3$ & $\mathrm{~S} 4$ & $\mathrm{~S} 5$ & $\mathrm{~S} 6$ & Artc1 & Sur7 & Artc2 & Sur8 & NK & RASIO \\
\hline $\mathrm{Z}$ & 0 & 0 & 0 & 0 & 0 & 0 & 0 & 0 & $\mathrm{M}+14500$ & $\begin{array}{c}- \\
14500\end{array}$ & $\mathrm{M}+11500$ & - & 2420000 & \\
\hline $\mathrm{S} 1$ & 0 & 0 & 1 & 0 & 0 & 0 & 0 & 0 & -720 & 720 & -720 & 720 & 6000 & 8,3 \\
\hline S2 & 0 & 0 & 0 & 1 & 0 & 0 & 0 & 0 & -1500 & 1500 & -500 & 500 & 10000 & 6,6 \\
\hline S3 & 0 & 0 & 0 & 0 & 1 & 0 & 0 & 0 & -2000 & 2000 & -1000 & 1000 & 260000 & 130 \\
\hline S4 & 0 & 0 & 0 & 0 & 0 & 1 & 0 & 0 & -360 & 360 & -360 & 360 & 18000 & 50 \\
\hline S5 & 0 & 0 & 0 & 0 & 0 & 0 & 1 & 0 & -300 & 300 & -300 & 300 & 134400 & 448 \\
\hline S6 & 0 & 0 & 0 & 0 & 0 & 0 & 0 & 1 & -21500 & 21500 & -19500 & 19500 & 1520000 & 70,6 \\
\hline X1 & 1 & 0 & 0 & 0 & 0 & 0 & 0 & 0 & 1 & -1 & 0 & 0 & 40 & \\
\hline X2 & 0 & 1 & 0 & 0 & 0 & 0 & 0 & 0 & 0 & 0 & 1 & -1 & 160 & \\
\hline
\end{tabular}

Tabel 9. Tabel iterasi Keempat

\begin{tabular}{|c|c|c|c|c|c|c|c|c|c|c|c|c|c|c|}
\hline VD & X1 & X2 & S1 & S2 & S3 & S4 & S5 & S6 & Artc1 & Sur7 & Artc2 & Sur8 & NK & RASIO \\
\hline Z & 0 & 0 & 0 & 0 & 0 & 0 & 0 & 0 & M & 0 & M+6667,15 & $-6667,15$ & 2516667,2 & \\
\hline S1 & 0 & 0 & 1 & $-0,504$ & 0 & 0 & 0 & 0 & 0 & 0 & -480 & 480 & 1200 & 2,5 \\
\hline Sur7 & 0 & 0 & 0 & 0,0007 & 0 & 0 & 0 & 0 & -1 & 1 & $-0,3333$ & 0,3333 & 6,6667 & 20 \\
\hline S3 & 0 & 0 & 0 & $-1,4$ & 1 & 0 & 0 & 0 & 0 & 0 & $-333,4$ & 333,4 & 246666,6 & 739,8 \\
\hline S4 & 0 & 0 & 0 & $-0,25$ & 0 & 1 & 0 & 0 & 0 & 0 & -240 & 240 & 15600 & 65 \\
\hline S5 & 0 & 0 & 0 & $-0,21$ & 0 & 0 & 1 & 0 & 0 & 0 & -200 & 200 & 132400 & 662 \\
\hline S6 & 0 & 0 & 0 & $-15,05$ & 0 & 0 & 0 & 1 & 0 & 0 & $-12334,05$ & 12334,05 & 1376665,95 & 111,6 \\
\hline X1 & 1 & 0 & 0 & 0,0007 & 0 & 0 & 0 & 0 & 0 & 0 & $-0,3333$ & 0,3333 & 46,6667 & \\
\hline X2 & 0 & 1 & 0 & 0 & 0 & 0 & 0 & 0 & 0 & 0 & 1 & -1 & 160 & \\
\hline
\end{tabular}


Tabel 10. Tabel Iterasi Kelima

\begin{tabular}{|c|c|c|c|c|c|c|c|c|c|c|c|c|c|c|}
\hline VD & X1 & X2 & S1 & S2 & S3 & S4 & S5 & S6 & Artc1 & Sur7 & Artc2 & Sur8 & NK & RASIO \\
\hline Z & 0 & 0 & 0 & 0 & 0 & 0 & 0 & 0 & M & 0 & M & 0 & 2533335,37 & \\
\hline Sur8 & 0 & 0 & 0,002 & $-0,001$ & 0 & 0 & 0 & 0 & 0 & 0 & -1 & 1 & 2,5 & \\
\hline Sur7 & 0 & 0 & $-0,0007$ & 0,0004 & 0 & 0 & 0 & 0 & -1 & 1 & 0 & 0 & 5,83345 & \\
\hline S3 & 0 & 0 & $-0,6668$ & $-0,466$ & 1 & 0 & 0 & 0 & 0 & 0 & 0 & 0 & 245833,1 & \\
\hline S4 & 0 & 0 & $-0,48$ & $-0,01$ & 0 & 1 & 0 & 0 & 0 & 0 & 0 & 0 & 15000 & \\
\hline S5 & 0 & 0 & $-0,4$ & $-0,01$ & 0 & 0 & 1 & 0 & 0 & 0 & 0 & 0 & 131900 & \\
\hline S6 & 0 & 0 & $-24,66$ & $-2,72$ & 0 & 0 & 0 & 1 & 0 & 0 & 0 & 0 & 1345830,82 & \\
\hline X1 & 1 & 0 & $-0,0007$ & 0,0004 & 0 & 0 & 0 & 0 & 0 & 0 & 0 & 0 & 45,83 & \\
\hline X2 & 0 & 1 & 0,002 & $-0,001$ & 0 & 0 & 0 & 0 & 0 & 0 & 0 & 0 & 162,5 & \\
\hline
\end{tabular}

Berdasarkan Tabel 10 dapat dilihat bahwa sudah tidak terdapat indikator negatif pada baris Z, sehingga ini merupakan penyelesaian optimal. Elemen terakhir pada baris tersebut menunjukkan bahwa pada $x_{1}=45,83$ dan $x_{2}=162,5$. Fungsi objektif tersebut mencapai penyelesaian maksimum pada $Z=2533335,37$.

Dalam menyelesaikan permasalahan tersebut peneliti juga menggunakan alat bantu berupa software Lindo. Lindo adalah sebuah software yang dapat digunakan untuk menyelesaikan permasalahan pemrograman linear. Perhitungan yang digunakan Lindo pada dasarnya menggunakan metode Simpleks. Hasil perhitungan menggunakan software Lindo ditunjukkan pada Gambar 2.

\section{LP OPTTMUM FOUND AT STEP 2}

\section{OBJECTIVE FUNCTION VALUE} 1) 2533333 .

$\begin{array}{ccc}\text { VARIABLE } & \text { VALUE } & \text { REDUCED COST } \\ \text { X1 } & 45.833332 & 0.000000 \\ \text { X2 } & 162.500000 & 0.000000 \\ \text { ROW } & \text { SLACK OR SURPLUS } & \text { DUAL PRICES } \\ 2 \text { ) } & 0.000000 & 13.888889 \\ 3) & 0.000000 & 3.000000 \\ 4) & 245833.328125 & 0.000000 \\ 5) & 15000.000000 & 0.000000 \\ 6) & 131900.000000 & 0.000000 \\ 7) & 2645833.250000 & 0.000000 \\ 8) & 5.833333 & 0.000000 \\ 9) & 2.500000 & 0.000000\end{array}$

NO. ITERATIONS $=2$

RANGES IN WHICH THE BASIS IS UNCHANGED:

\begin{tabular}{|c|c|c|c|}
\hline \multicolumn{4}{|c|}{ OBJ COEFFICIENT RANGES } \\
\hline \multirow{2}{*}{ VARIABLE } & CURRENT & ALLOWABLE & ALLOWABLE \\
\hline & COEF & INCREASE & DECREASE \\
\hline \multirow{3}{*}{$\begin{array}{l}\mathrm{X} 1 \\
\mathrm{X} 2\end{array}$} & 14500.000000 & 20000.000000 & 2999.999756 \\
\hline & 11500.000000 & 2999.999756 & 6666.666504 \\
\hline & \multicolumn{3}{|c|}{ RIGHTHAND SIDE RANGES } \\
\hline \multirow[t]{2}{*}{ ROW } & CURRENT & ALLOWABLE & ALLOWABLE \\
\hline & RHS & INCREASE & DECREASE \\
\hline $\begin{array}{l}2 \\
3\end{array}$ & $\begin{array}{l}150000.000000 \\
150000.000000\end{array}$ & $\begin{array}{l}8400.000000 \\
2500.000000\end{array}$ & $\begin{array}{l}1199.999878 \\
5833.333008\end{array}$ \\
\hline 4 & 500000.000000 & INFINITY & 245833.328125 \\
\hline 5 & 90000.000000 & INFINITY & 15000.000000 \\
\hline 6 & 194400.000000 & INFINITY & 131900.000000 \\
\hline 7 & 5500000.000000 & INFINITY & 2645833.250000 \\
\hline 8 & 40.000000 & 5.833333 & INFINITY \\
\hline 9 & 160.000000 & 2.500000 & INFINITY \\
\hline
\end{tabular}

Gambar 2. Hasil Perhitungan Dengan Software Lindo 6.1 
Dari hasil perhitungan optimalisasi keuntungan dengan metode Simpleks diperoleh hasil yang maksimal yaitu jika Industri Rumahan Kopi Bubuk Asli Lampung yang telah memproduksi kopi bubuk yang dikemas dengan bungkus yang bagus dan menarik sebanyak 46 kemasan dan kopi bubuk yang dikemas dengan bungkus yang biasa sebanyak 163 kemasan akan menghasilkan keuntungan sebesar Rp. 2.541.500.

Hasil pengolahan model optimalisasi produksi yang ditampilkan pada Tabel 11, menunjukkan bahwa produksi yang dilakukan Industri Rumahan Kopi Bubuk Asli Lampung pada kondisi nyata (faktual) belum optimal. Hal ini dapat dilihat dari kondisi total produksi yang ada berbeda dengan kondisi optimalnya.

Tabel 11. Produksi Optimal Kopi Bubuk

\begin{tabular}{|c|c|c|c|}
\hline \multirow{2}{*}{ No } & \multirow{2}{*}{ Variabel } & \multicolumn{2}{|c|}{ Tingkat Produksi } \\
\cline { 3 - 4 } & & Faktual & Optimal \\
\hline 1. & $x 1$ & 40 & 46 \\
\hline 2. & $x 2$ & 160 & 163 \\
\hline
\end{tabular}

Berdasarkan Tabel 11 dapat dilihat bahwa jumlah produksi faktual kopi bubuk pada industri rumahan tersebut sebanyak 40 kemasan merk $\mathrm{x}_{1}$ dan 160 kemasan merk $\mathrm{x}_{2}$. Sedangkan berdasarkan hasil pengolahan optimal dengan menggunakan tabel Simpleks dan software Lindo tingkat produksi kopi bubuk sebanyak 46 kemasan merk $\mathrm{x}_{1}$ dan 163 kemasan merk $\mathrm{x}_{2}$.

\section{Kesimpulan}

Berdasarkan perhitungan optimalisasi dengan metode Simpleks dan berbantu software Lindo maka dapat disimpulkan bahwa dengan memanfaatkan ketersediaan yang ada, model optimalisasi proses produksi Industri Rumahan Kopi Bubuk Asli Lampung adalah dengan memproduksi kopi bubuk yang dikemas dengan bungkus yang bagus dan menarik sebanyak 46 kemasan sedangkan kopi bubuk yang dikemas dengan bungkus yang biasa sebanyak 163 kemasan akan menghasilkan keuntungan sebesar Rp. 2.541.500.

\section{Referensi}

[1] N Astuti, L Linawati, dan T Mahatma, Penerapan model linear goal programming untuk optimasi perencanaan produksi, Prosiding Seminar Nasional Sains dan Pendidikan Sains VIII, UKSW Salatiga, Vol. 4, No. 1, 2013. h. 464-471

[2] P Ferdias, E Savitri. Analisis Materi Volume Benda Putar pada Aplikasi Cara Kerja Piston di Mesin Kendaraan Roda Dua, Al-Jabar: Jurnal Pendidikan Matematika Vol. 6, No. 2, 2015. h.108-119.

[3] Hamni, Arinal, Gusri Akhyar, Suryadiwansa, Yanuar Burhanuddin, Tarkono. (2013). "Potensi Pengembangan Teknologi Proses Produksi Kopi Lampung”. Jurnal Mechanical 4, no. 1 h.45-51.

[4] E Herjanto, Sains Manajemen: Analisis Kuantitatif Untuk Pengambilan Keputusan, Jakarta: Grasindo. 2009.

[5] A Irawan, Perancangan Aplikasi Optimasi Produksi Pada CV. Indahserasi Menggunakan Metode Simpleks, Jurnal Ilmiah Infotek, Vol. 1, No. 3, 2016.

[6] R Rachman, Optimalisasi Produksi Di Industri Garment Dengan Menggunakan Metode Simpleks, Jurnal Informatika Vol. 4, No. 1, 2017.

[7] R Rakhmawati, Aktivitas Matematika Berbasis Budaya pada Masyarakat Lampung, Al-jabar: Jurnal Pendidikan Matematika Vol. 7, no. 2, 2016. h.221-230.

[8] A Sessu, Pengantar Matematika Ekonomi, Jakarta: PT. Bumi Aksara, 2014. 
[9] T Sriwidadi, E Agustina, Analisis Optimalisasi Produksi dengan Linear Programming Melalui Metode Simpleks, Binus Business Review, Vol. 4, No. 2, 2013. h.725-741.

[10] D Wirdasari, Metode Simpleks dalam Program Linier, Jurnal Saintikom Vol. 6, No. 1, 2009. h. 277.

[11] M Yahya, Analisis Kelayakan dan Strategi Pengembangan Agroindustri Kopi di Perusahaan Daerah Perkebunan Kahyangan Jember, Skripsi, Program Studi Agribisnis, Fakultas Pertanian, Universitas Jember, 2016.

[12] FH Badruzzaman, E Harahap, E Kurniati, MD Johansyah, Pengendalian Persediaan Produksi Hijab Berdasarkan Economic Production Quantity di RAR Azkia, Jurnal Matematika Vol. 16, No. 2, 2017.

[13] A Suryadi, E Harahap, Pemeringkatan Pegawai Berprestasi Menggunakan Metode AHP (Analytic Hierarchy Process) di PT. XYZ, Jurnal Matematika, Vol. 16, No. 2, 2017.

[14] IL Nur'aini, E Harahap, FH Badruzzaman, D Darmawan, Pembelajaran Matematika Geometri Secara Realistis Dengan GeoGebra, Jurnal Matematika, Vol. 16, No. 2, 2017. 